\title{
Pengaruh Metode Pemupukan Kalium terhadap Pertumbuhan dan Produktivitas Padi Gogo (Oryza sativa L.) Varietas IPB 9G
}

\section{The Effect of Potassium Fertilizer methods on Growth and Production of Upland Rice (Oryza sativa L.) Variety IPB 9 G}

\section{Rika Riyani dan Heni Purnamawati*}

\author{
Departemen Agronomi dan Hortikultura, Fakultas Pertanian, Institut Pertanian Bogor \\ (Bogor Agricultural University), Jl. Meranti, Kampus IPB Darmaga, Bogor 16680, Indonesia \\ Telp.\& Faks.62-251-8629353 e-mail agrohort@apps.ipb.ac.id \\ *Penulis Korespondensi : henipurnamawati1@ gmail.com
}

Disetujui : 21 Mei 2018 / Published Online September 2019

\begin{abstract}
Upland rice is rice cultivation on dry land. Upland rice has low productivity. The treatment of potassium fertilization methods was done to find out the growth response and productivity of upland rice Variety IPB 9G. The study was conducted for 5 months starting from November 2017 until April 2018 in the Experimental Garden IPB Sawah Baru Dry Land. The research design was Randomized Complete Block Design (RCBD) with one factor which is potassium fertilizer methods consist of 4 level that are $\mathrm{Pl}$ ( $\mathrm{KCl} 100$ $\left.\mathrm{kg} \mathrm{ha}^{-1}\right), P 2\left(\mathrm{KCl} 50 \mathrm{~kg} \mathrm{ha}^{-1}+\mathrm{KCl} 50 \mathrm{~kg} \mathrm{ha}^{-1}\right), P 3\left(\mathrm{KCl} 50 \mathrm{~kg} \mathrm{ha}^{-1}+3 \times \mathrm{KNO}_{3} 22 \mathrm{~kg} \mathrm{ha}^{-1}\right)$, and P4 (KCl 50

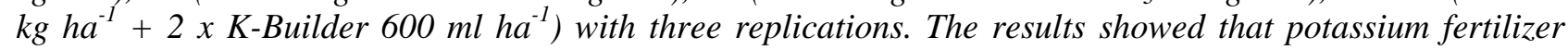
method had significant effect on the growth variables such as plant height at 4 weeks after planting, number of tillers at 11 and 12 weeks after planting and Leaf Color Chart scores at 5 weeks after planting, number of total tillers, productive tillers, unproductive tillers, and height of harvest on the harvest variables of panicle length, grain weight of tile, dried harvested grain productivity, and dried milled grain productivity. Fertilization of potassium P1, P3, and P4 levels can increase the weight of grain tiles, dried harvested grain productivity, and dried milled grain productivity.
\end{abstract}

Keywords: dried harvested grain productivity, wet grain productivity, grain, panicles, rice tillers.

\begin{abstract}
ABSTRAK
Padi gogo merupakan budi daya padi di lahan kering. Padi gogo memiliki produktivitas yang masih rendah. Perlakuan metode pemupukan kalium dilakukan untuk mengetahui respon pertumbuhan dan produktivitas padi gogo varietas IPB 9G. Penelitian dilaksanakan selama 5 bulan dimulai dari November 2017 hingga April 2018 di Kebun Percobaan IPB Sawah Baru Lahan Kering. Rancangan perlakuan yang digunakan adalah Rancangan Kelompok Lengkap Teracak (RKLT) dengan satu faktor yaitu metode pemupukan kalium yang terdiri dari 4 taraf yaitu P1 (KCl $\left.100 \mathrm{~kg} \mathrm{ha}^{-1}\right), \mathrm{P} 2\left(\mathrm{KCl} 50 \mathrm{~kg} \mathrm{ha}^{-1}+\mathrm{KCl} 50 \mathrm{~kg} \mathrm{ha}^{-1}\right)$, $\mathrm{P} 3\left(\mathrm{KCl} 50 \mathrm{~kg} \mathrm{ha}^{-1}+3 \mathrm{x} \mathrm{KNO}_{3} 22 \mathrm{~kg} \mathrm{ha}^{-1}\right)$, dan P4 $\left(\mathrm{KCl} 50 \mathrm{~kg} \mathrm{ha}^{-1}+2 \times \mathrm{K}^{-B u i l d e r} 600 \mathrm{ml} \mathrm{ha}^{-1}\right)$ dengan 3 kali ulangan. Hasil penelitian menunjukkan perlakuan pemupukan kalium berpengaruh nyata terhadap peubah pertumbuhan yaitu tinggi tanaman pada 4 MST, jumlah anakan pada 11 dan 12 MST, skor Bagan Warna Daun (BWD) pada 5 MST, jumlah anakan total, jumlah anakan produktif, jumlah anakan tidak produktif, dan tinggi tanaman panen serta berpengaruh nyata pada komponen hasil panen yaitu panjang malai, bobot gabah ubinan, produktivitas GKP, dan produktivitas GKG. Pemupukan kalium taraf P1, P3, dan P4 mampu meningkatkan bobot gabah ubinan, produktivitas GKP, dan produktivitas GKG.
\end{abstract}

Kata kunci: anakan padi, gabah, malai, produktivitas GKP, produktivitas GKG. 


\section{PENDAHULUAN}

Padi (Oryza sativa L.) merupakan tanaman penghasil beras yang menjadi makanan pokok sebagian besar masyarakat Indonesia. Kebutuhan beras di Indonesia setiap tahunnya meningkat seiring dengan meningkatnya pertumbuhan penduduk. Pada tahun 2017, konsumsi beras ratarata masyarakat Indonesia sebesar $1.57 \mathrm{~kg}$ per kapita per minggu. Ketersediaan pangan untuk beras dapat dilakukan melalui peningkatan produktivitas tanaman padi. Produksi padi Indonesia pada tahun 2017 sebesar 81,072,701 ton dan produktivitas sebesar 5.165 ton $\mathrm{ha}^{-1}$ (BPS, 2017). Hasil tersebut harus terus ditingkatkan untuk mengantisipasi krisis pangan dan mencapai swasembada beras.

Terdapat dua jenis budidaya padi yang banyak dilakukan di Indonesia, yaitu padi sawah dan padi gogo. Padi sawah adalah budi daya padi pada lahan sawah atau lahan basah. Selain ditanam di sawah, padi dapat juga dibudidayakan di lahan kering. Budi daya padi di lahan kering disebut padi gogo atau padi ladang. Padi gogo menyumbang beras nasional relatif kecil yaitu sebesar 5.01\% (BPS, 2014). Menurut BPS (2017), padi gogo memiliki produktivitas rendah yaitu sebesar 3.3 ton ha ${ }^{-1}$ dengan luas panen 1155729 ha. Hal ini jauh lebih kecil dibandingkan produktivitas padi sawah sebesar 5.3 ton $\mathrm{ha}^{-1}$. Peningkatan produktivitas padi gogo dapat dilakukan melalui penggunaan varietas unggul dan penerapan teknik budidaya (Suhendrata dan Budiyanto, 2012).

Permasalahan dalam produksi padi gogo umumnya meliputi ketersediaan air dan unsur hara tanah. Pemenuhan kebutuhan air padi gogo tergantung pada curah hujan yang turun. Lahan kering memiliki kandungan unsur hara yang rendah. Adanya masalah kesuburan tanah pada lahan kering, perlu upaya dan tindakan untuk mengatasi permasalahan tersebut. Upaya yang dapat dilakukan adalah melalui perbaikan teknik budidaya padi gogo, salah satunya dengan melakukan pemupukan. Pemupukan penting sebagai salah satu faktor yang sangat menentukan produktivitas tanaman padi. Asupan unsur hara yang diperoleh tanaman bersumber dari pupuk yang diberikan selama pertanaman. Menurut Sahardi et al. (2014), pemupukan merupakan cara mutlak untuk memenuhi ketersediaan unsur hara tanah yang dibutuhkan tanaman dan meningkatkan produktivitas.

Menurut Puspadewi et al. (2016), tanaman dapat tumbuh dengan optimal apabila dosis pupuk yang diberikan tepat. Padi gogo memerlukan suplai nutrisi unsur hara yang seimbang terutama untuk pengisian bulir padi. Selain nitrogen dan fosfor, kalium penting dalam mempengaruhi produktivitas padi gogo. Menurut Subandi (2013), unsur kalium adalah unsur hara yang dibutuhkan tanaman dalam jumlah banyak, bahkan untuk tanaman padi dan ubi kayu melebihi kebutuhan $\mathrm{N}$.

Kalium merupakan salah satu unsur hara makro bagi tanaman yang tidak dapat digantikan oleh unsur hara lainnya. Pemberian pupuk kalium pada tanaman padi dapat meningkatkan jumlah gabah per malai, persentase gabah bernas, dan bobot 1000 butir gabah (Dobermann dan Fairhurst, 2000). Penggunaan pupuk kalium dengan jenis dan komposisi yang tepat diharapkan dapat mempengaruhi pertumbuhan serta meningkatkan produksi padi gogo. Penelitian ini bertujuan untuk mempelajari respon pertumbuhan dan produktivitas padi gogo varietas IPB 9G terhadap metode pemupukan kalium.

\section{BAHAN DAN METODE}

Penelitian ini telah dilaksanakan di lahan kering Kebun Percobaan IPB Sawah Baru, Kecamatan Dramaga, Kabupaten Bogor. Waktu pelaksanaan penelitian dimulai pada bulan November 2017 sampai April 2018. Penanaman padi gogo dilaksanakan pada bulan November 2017 dan pengujian pasca panen bulan April 2018 di Laboratorium Pasca Panen, Departemen Agronomi dan Hortikultura, Institut Pertanian Bogor. Bahan yang digunakan dalam penelitian ini yaitu padi gogo varietas IPB 9G, pupuk kandang, kapur, karbofuran, pestisida, pupuk Urea, pupuk SP-36, pupuk $\mathrm{KCl}$, pupuk $\mathrm{KNO}_{3}$, dan pupuk K-Builder. Alat yang digunakan yaitu alat-alat pertanian, perontok padi, oven, moisture tester, sprayer, kamera, timbangan digital, meteran, mikroskop, dan BWD (Bagan Warna Daun).

Penelitian ini dilakukan dengan menggunakan Rancangan Kelompok Lengkap Teracak (RKLT) satu faktor yaitu metode pemupukan kalium yang terdiri dari 4 taraf dan 3 ulangan, sehingga terdapat 12 satuan percobaan. Taraf perlakuan yang digunakan $\mathrm{P} 1(\mathrm{KCl} 100 \mathrm{~kg}$ $\left.\mathrm{ha}^{-1}\right), \mathrm{P} 2\left(\mathrm{KCl} 50 \mathrm{~kg} \mathrm{ha}^{-1}+\mathrm{KCl} 50 \mathrm{~kg} \mathrm{ha}^{-1}\right), \mathrm{P} 3$ $\left(\mathrm{KCl} 50 \mathrm{~kg} \mathrm{ha}^{-1}+3 \times \mathrm{KNO}_{3} 22 \mathrm{~kg} \mathrm{ha}^{-1}\right)$, dan $\mathrm{P} 4$ (KCl $50 \mathrm{~kg} \mathrm{ha}^{-1}+2 \times$ K-Builder $\left.600 \mathrm{ml} \mathrm{ha}^{-1}\right)$. Pemupukan Urea, SP-36, $\mathrm{KCl}$, dan $\mathrm{KNO}_{3}$ diberikan melalui tanah dan K-Builder diberikan melalui penyemprotan pada daun. Taraf perlakuan metode pemupukan kalium dapat dilihat pada Tabel 1. Pelaksanaan penelitian dimulai dengan pengolahan tanah dua minggu sebelum tanam dengan pemberian pupuk kandang dan kapur, kemudian dilakukan pembuatan petak percobaan berukuran berukuran $3 \mathrm{~m}$ x $3 \mathrm{~m}$ sebanyak 12 petak. 
Tabel 1. Perlakuan metode pemupukan pada padi gogo

\begin{tabular}{|c|c|c|c|c|c|c|}
\hline \multicolumn{7}{|l|}{ Taraf } \\
\hline & Pupuk & 0 & 2 & 6 & 8 & 10 \\
\hline Perlakuan & & MST & MST & MST & MST & MST \\
\hline \multirow[t]{3}{*}{$\mathrm{P} 1$} & Urea & $200 \mathrm{~kg} \mathrm{ha}^{-1}$ & $34 \mathrm{~kg} \mathrm{ha}^{-1}$ & $100 \mathrm{~kg} \mathrm{ha}^{-1}$ & $67 \mathrm{~kg} \mathrm{ha}^{-1}$ & - \\
\hline & SP36 & $100 \mathrm{~kg} \mathrm{ha}^{-1}$ & - & - & - & - \\
\hline & $\mathrm{KCl}$ & $100 \mathrm{~kg} \mathrm{ha}^{-1}$ & - & - & - & - \\
\hline \multirow[t]{3}{*}{$\mathrm{P} 2$} & Urea & $200 \mathrm{~kg} \mathrm{ha}^{-1}$ & $34 \mathrm{~kg} \mathrm{ha}^{-1}$ & $100 \mathrm{~kg} \mathrm{ha}^{-1}$ & $67 \mathrm{~kg} \mathrm{ha}^{-1}$ & - \\
\hline & SP36 & $100 \mathrm{~kg} \mathrm{ha}^{-1}$ & - & - & - & - \\
\hline & $\mathrm{KCl}$ & $50 \mathrm{~kg} \mathrm{ha}^{-1}$ & ـ & - & $50 \mathrm{~kg} \mathrm{ha}^{-1}$ & - \\
\hline \multirow[t]{4}{*}{ P3 } & Urea & $200 \mathrm{~kg} \mathrm{ha}^{-1}$ & $34 \mathrm{~kg} \mathrm{ha}^{-1}$ & $100 \mathrm{~kg} \mathrm{ha}^{-1}$ & $67 \mathrm{~kg} \mathrm{ha}^{-1}$ & - \\
\hline & SP36 & $100 \mathrm{~kg} \mathrm{ha}^{-1}$ & - & - & - & - \\
\hline & $\mathrm{KCl}$ & $50 \mathrm{~kg} \mathrm{ha}^{-1}$ & - & - & - & - \\
\hline & $\mathrm{KNO}_{3}$ & - & $22 \mathrm{~kg} \mathrm{ha}^{-1}$ & $22 \mathrm{~kg} \mathrm{ha}^{-1}$ & $22 \mathrm{~kg} \mathrm{ha}^{-1}$ & - \\
\hline \multirow[t]{4}{*}{ P4 } & Urea & $200 \mathrm{~kg} \mathrm{ha}^{-1}$ & $34 \mathrm{~kg} \mathrm{ha}^{-1}$ & $100 \mathrm{~kg} \mathrm{ha}^{-1}$ & $67 \mathrm{~kg} \mathrm{ha}^{-1}$ & - \\
\hline & SP36 & $100 \mathrm{~kg} \mathrm{ha}^{-1}$ & - & - & - & - \\
\hline & $\mathrm{KCl}$ & $50 \mathrm{~kg} \mathrm{ha}^{-1}$ & - & - & - & - \\
\hline & K-Builder & - & - & - & 600 & 600 \\
\hline
\end{tabular}

Penanaman benih padi gogo dengan cara ditugal hingga kedalaman tanah $2-3 \mathrm{~cm}$ dan jumlah benih yang ditanam 5 benih per lubang dengan jarak tanam $25 \mathrm{~cm} \times 25 \mathrm{~cm}$ x $50 \mathrm{~cm}$ jajar legowo (2:1). Karbofuran diberikan pada lubang tanam. Benih padi yang tidak tumbuh dilakukan penyulaman 1 minggu setelah tanam. Pemeliharaan tanaman meliputi penyiraman, pengendalian hama, penyakit, dan gulma. Pengendalian gulma dilakukan setiap minggu umur tanaman dengan manual.

Tabel 2. Hasil analisis sifat kimia tanah Kebun Percobaan IPB Sawah Baru

\begin{tabular}{lrc}
\hline Sifat Rata-rata & Rata-rata & Kategori \\
Kriteria & 19.54 & Sedang \\
\hline $\mathrm{KTK}\left(\mathrm{cmol}^{(+)} \mathrm{kg}^{-1}\right)$ & 5.13 & Sedang \\
$\mathrm{Ca}\left(\mathrm{cmol}^{(+)} \mathrm{kg}^{-1}\right)$ & 2.41 & Tinggi \\
$\mathrm{Mg}\left(\mathrm{cmol}^{(+)} \mathrm{kg}^{-1}\right)$ & 0.25 & Rendah \\
$\mathrm{K}\left(\mathrm{cmol}^{(+)} \mathrm{kg}^{-1}\right)$ & 0.20 & Rendah \\
$\mathrm{Na}\left(\mathrm{cmol}^{(+)} \mathrm{kg}^{-1}\right)$ & 5.18 & Rendah \\
$\mathrm{pH}$ pada H2O & 4.98 & Rendah \\
$\mathrm{pH}$ pada KCl & 0.21 & Sedang \\
$\mathrm{N}$ total $(\%)$ & 1.83 & Rendah \\
$\mathrm{C}-$ Organik $(\%)$ & 185.86 & Sangat tinggi \\
P total $\left(\mathrm{mg} 100 \mathrm{~g}^{-1}\right)$ & 16.30 & Rendah \\
K total $\left(\mathrm{mg} 100 \mathrm{~g}^{-1}\right)$ & 17.06 & Sedang \\
P tersedia $(\mathrm{ppm})$ & &
\end{tabular}

Sumber : Tsalitsan, 2017

Pengendalian hama dan penyakit dilakukan dengan pengawasan secara rutin terhadap gejala-gejala serangan yang terjadi di lapangan. Ketika tanaman padi gogo terkena serangan, kegiatan pengendalian dengan pestisida dilakukan untuk menghindari kegagalan panen. Pemanenan padi gogo dilakukan ketika butir gabahnya menguning sekitar $80 \%$, dan tangkai malai sudah menunduk diikuti dengan penuaan batang. Pemanenan dilakukan dengan cara manual kemudian dirontokkan.

Peubah yang diamati terdiri dari komponen pertumbuhan dan komponen hasil. Pengamatan dilakukan dengan mengambil 5 rumpun tanaman contoh pada masing - masing taraf perlakuan secara acak. Peubah yang diamati meliputi tinggi tanaman, jumlah anakan, Bagan Warna Daun (BWD), anakan total, anakan produktif, anakan tidak produktif, tinggi tanaman panen, panjang malai, dan kadar air GKP, jumlah gabah per malai, gabah isi, gabah hampa, persentase gabah isi, bobot 1000 butir gabah, bobot gabah per rumpun, bobot gabah ubinan, produktivitas GKP, dan produktivitas GKG. Data yang diperoleh dari hasil pengamatan dianalisis untuk mengetahui pengaruh perlakuan pemupukan kalium dengan melakukan uji F pada taraf nyata $\alpha=5 \%$. Apabila terdapat pengaruh nyata terhadap parameter yang diamati maka dilakukan uji lanjut Beda Nyata Jujur (BNJ) / Honestly Significant Difference (HSD).

\section{HASIL DAN PEMBAHASAN}

\section{Kondisi Pertanaman}

Penelitian ini dilaksanakan pada bulan November 2017 hingga April 2018. Tempat pelaksanaan penelitian dilakukan di Kebun Percobaan IPB Sawah Baru Lahan Kering, Dramaga, Bogor yang memiliki jenis tanah latosol yang berasal dari batuan induk tuf volkan hasil letusan Gunung Salak (Nursyamsi dan Suprihati, 2005). Menurut hasil analisis tanah penelitian Tsalitsan (2017), Kebun Percobaan IPB Sawah Baru Lahan Kering memiliki $\mathrm{pH}$ masam. Kandungan unsur K, C-org, Na, dan Ktotal tergolong rendah. Kandungan KTK, Ca, Ntotal, dan $\mathrm{P}$ tersedia tergolong sedang. 
Tabel 3. Rekapitulasi sidik ragam pengaruh metode pemupukan kalium terhadap pertumbuhan dan komponen hasil padi gogo varietas IPB 9G

\begin{tabular}{|c|c|c|}
\hline 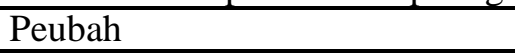 & Perlakuan Pemupukan Kalium & KK (\%) \\
\hline \multicolumn{3}{|c|}{ Pertumbuhan Tanaman } \\
\hline \multicolumn{3}{|l|}{ Tinggi Tanaman } \\
\hline 4 MST & $*$ & 4.89 \\
\hline $5 \mathrm{MST}$ & tn & 9.62 \\
\hline $6 \mathrm{MST}$ & tn & 12.93 \\
\hline $7 \mathrm{MST}$ & tn & 14.35 \\
\hline $8 \mathrm{MST}$ & tn & 10.17 \\
\hline $9 \mathrm{MST}$ & tn & 9.51 \\
\hline 10 MST & tn & 7.95 \\
\hline $11 \mathrm{MST}$ & tn & 7.72 \\
\hline $12 \mathrm{MST}$ & tn & 6.89 \\
\hline \multicolumn{3}{|l|}{ Jumlah Anakan } \\
\hline $4 \mathrm{MST}$ & $\operatorname{tn}$ & 16.27 \\
\hline 5 MST & $\operatorname{tn}$ & 18.61 \\
\hline $6 \mathrm{MST}$ & $\operatorname{tn}$ & 19.20 \\
\hline $7 \mathrm{MST}$ & $\operatorname{tn}$ & 12.49 \\
\hline $8 \mathrm{MST}$ & $\operatorname{tn}$ & 14.36 \\
\hline $9 \mathrm{MST}$ & th & 10.17 \\
\hline 10 MST & th & 10.47 \\
\hline $11 \mathrm{MST}$ & $*$ & 4.34 \\
\hline 12 MST & $*$ & 3.49 \\
\hline \multicolumn{3}{|l|}{ Bagan Warna Daun } \\
\hline $4 \mathrm{MST}$ & $\operatorname{tn}$ & 7.22 \\
\hline $5 \mathrm{MST}$ & $*$ & 6.92 \\
\hline $6 \mathrm{MST}$ & tn & 5.79 \\
\hline $7 \mathrm{MST}$ & tn & 8.98 \\
\hline $8 \mathrm{MST}$ & tn & 8.77 \\
\hline $9 \mathrm{MST}$ & $\operatorname{tn}$ & 7.36 \\
\hline 10 MST & $\operatorname{tn}$ & 0.00 \\
\hline $11 \mathrm{MST}$ & $\operatorname{tn}$ & 0.00 \\
\hline 12 MST & $\operatorname{tn}$ & 2.53 \\
\hline Jumlah Anakan Total & $*$ & 3.88 \\
\hline Jumlah Anakan Produktif & ** & 4.55 \\
\hline Jumlah Anakan Tidak Produktif & ** & 22.84 \\
\hline Tinggi Tanaman Panen & $* *$ & 1.84 \\
\hline \multicolumn{3}{|c|}{ Komponen Hasil Tanaman } \\
\hline Panjang Malai & $*$ & 2.35 \\
\hline Jumlah Gabah Total & $\operatorname{tn}$ & 14.73 \\
\hline Jumlah Gabah Isi & $\operatorname{tn}$ & 18.20 \\
\hline Jumlah Gabah Hampa & $\operatorname{tn}$ & 23.85 \\
\hline Persentase Gabah Isi & $\operatorname{tn}$ & 8.90 \\
\hline Bobot 1000 Butir & tn & 2.77 \\
\hline Bobot Gabah per Rumpun & tn & 8.75 \\
\hline Bobot Gabah Ubinan & ** & 7.27 \\
\hline Produktivitas GKP & $* *$ & 7.27 \\
\hline Produktivitas GKG & $* *$ & 7.42 \\
\hline
\end{tabular}

Keterangan: *: nyata pada taraf $0.05, * *$ nyata pada taraf 0.01 , tn: tidak nyata.

Menurut BMKG (2017, 2018), rata-rata curah hujan wilayah Dramaga mengalami fluktuasi. Curah hujan pada bulan November 2017, Desember 2017, Januari 2018, Februari 2018, dan Maret 2018 masing-masing sebesar $207.0 \mathrm{~mm}$ per bulan, $181.2 \mathrm{~mm}$ per bulan, 189.2 $\mathrm{mm}$ per bulan, $358.9 \mathrm{~mm}$ per bulan dan 122.7 mm per bulan. Pada saat awal pertumbuhan (4-5 MST), tanaman padi mengalami kekeringan karena curah hujan harian yang rendah dan sedikitnya sumber air sehingga dilakukan penyiraman.

Tanaman menunjukkan gejala serangan sundep pada umur 3 MST dan saat tanaman 
berumur 13 MST terserang hama walang sangit dan belalang. Hama dan penyakit lain yang menyerang yaitu penggulung daun (Cnaphalocrosis medinalis), beluk, kerdil hampa, hawar daun bakteri (kresek), dan burung bondol. Serangan hama dan penyakit pada pertanaman dikendalikan secara kimia menggunakan pestisida, sedangkan hama burung bondol dikendalikan dengan pemasangan jaring.

Penyiangan gulma dilakukan dari 2 MST hingga menjelang panen. Jenis gulma yang terdapat pada areal pertanaman terdiri dari gulma rumput (Eleusine indica, Rottboellia exaltata, Digitaria sp.), teki (Cyperus sp.), dan daun lebar (Mimosa pudica, Wedelia biflora, Ageratum conyzoides, Asystasia intrusa, dan Cleome rutidospermae). Pengendalian gulma dilakukan dengan cara manual menggunakan cangkul dan kored.

\section{Rekapitulasi Sidik Ragam Pengaruh Metode Pemupukan Kalium terhadap Pertumbuhan dan Komponen Hasil Tanaman}

Hasil sidik ragam menunjukkan bahwa metode perlakuan pemupukan kalium memberikan pengaruh berbeda-beda terhadap peubah yang diamati (Tabel 3). Metode pemupukan kalium berpengaruh nyata terhadap tinggi tanaman pada 4 MST, jumlah anakan pada 11 dan 12 MST, skor Bagan Warna Daun (BWD) pada 5 MST dan berpengaruh sangat nyata pada peubah anakan produktif, anakan tidak produktif, dan tinggi tanaman panen serta memberikan pengaruh nyata pada anakan total. Pada peubah komponen hasil, metode pemupukan kalium berpengaruh sangat nyata terhadap bobot gabah ubinan, produktivitas GKP, dan produktivitas GKG dan memberikan pengaruh nyata terhadap panjang malai tetapi tidak berpengaruh nyata pada jumlah gabah total, jumlah gabah isi, jumlah gabah hampa, persentase gabah isi, bobot 1000 butir, dan bobot gabah per rumpun.

\section{Pengaruh Metode Pemupukan Kalium terhadap Pertumbuhan Tanaman}

Peubah yang diamati untuk mempelajari pertumbuhan tanaman yaitu tinggi tanaman, jumlah anakan, Skor Bagan Warna Daun (BWD), jumlah anakan total, jumlah anakan produktif, jumlah anakan tidak produktif, tinggi tanaman panen, dan kerapatan stomata.

\section{Tinggi Tanaman}

Pertumbuhan tinggi tanaman padi varietas IPB 9G dapat dilihat pada Tabel 4. Tinggi tanaman merupakan indikator pertumbuhan untuk mengukur dan mengetahui pengaruh perlakuan. Pada saat tanaman berumur 12 MST, rata-rata tinggi tanaman yang dihasilkan dari keempat taraf lebih tinggi dibandingkan tinggi tanaman pada deskripsi varietas yaitu $98 \mathrm{~cm}$.

Perlakuan metode pemupukan kalium berpengaruh nyata terhadap tinggi tanaman pada 4 MST dan tidak berpengaruh nyata pada 5 MST hingga akhir pengamatan. Pada saat tanaman berumur 4 MST, taraf perlakuan P3 mampu meningkatkan tinggi tanaman dibandingkan P2, tetapi tidak berdeda nyata dengan P1 dan P4. Tanaman mendapatkan unsur hara $\mathrm{N}$ dari pemupukan urea yang diaplikasikan pada saat tanam dan berumur 2 MST, sehingga ketersediaan hara $\mathrm{N}$ termanfaatkan dengan baik dan digunakan untuk pertumbuhan tinggi tanaman.

Pada umur 4 MST tanaman padi masih banyak melakukan adaptasi di lapangan dari benih menjadi tanaman baru sehingga pada saat unsur hara tersedia dalam tanah, tanaman mampu menyerap hara tersedia dengan baik.

Tabel 4. Rata-rata pertumbuhan tinggi tanaman padi varietas IPB 9G pada perlakuan metode pemupukan kalium

\begin{tabular}{|c|c|c|c|c|c|c|c|c|c|}
\hline \multirow{2}{*}{ Taraf } & \multicolumn{9}{|c|}{ Tinggi Tanaman $(\mathrm{cm})$} \\
\hline & 4 & 5 & 6 & 7 & 8 & 9 & 10 & 11 & 12 \\
\hline & MST & MST & MST & MST & MST & MST & MST & MST & MST \\
\hline $\mathrm{P} 0$ & $37.40 \mathrm{ab}$ & 40.73 & 49.33 & 59.34 & 66.47 & 74.93 & 95.13 & 101.73 & 109.90 \\
\hline P1 & $34.93 \mathrm{~b}$ & 37.27 & 43.47 & 49.47 & 56.60 & 64.17 & 88.13 & 93.73 & 101.87 \\
\hline $\mathrm{P} 2$ & $40.60 \mathrm{a}$ & 43.87 & 53.20 & 62.77 & 68.17 & 75.77 & 100.47 & 105.33 & 115.93 \\
\hline P3 & $38.20 \mathrm{ab}$ & 41.33 & 49.27 & 57.63 & 65.55 & 72.67 & 97.77 & 102.57 & 110.17 \\
\hline Rata-rata & 37.78 & 40.80 & 48.82 & 57.30 & 64.20 & 71.89 & 95.38 & 100.84 & 109.47 \\
\hline
\end{tabular}

Keterangan: Angka yang diikuti huruf berbeda pada kolom yang sama berbeda nyata berdasarkan hasil Honestly Significant Difference (HSD) pada taraf $\alpha=0.05, \mathrm{P} 1\left(\mathrm{KCl} 100 \mathrm{~kg} \mathrm{ha}^{-1}\right), \mathrm{P} 2\left(\mathrm{KCl} 50 \mathrm{~kg} \mathrm{ha}^{-1}+\mathrm{KCl} 50 \mathrm{~kg}\right.$ $\left.\mathrm{ha}^{-1}\right), \mathrm{P} 3\left(\mathrm{KCl} 50 \mathrm{~kg} \mathrm{ha}^{-1}+3 \mathrm{x} \mathrm{KNO}_{3} 22 \mathrm{~kg} \mathrm{ha}^{-1}\right), \mathrm{P} 4\left(\mathrm{KCl} 50 \mathrm{~kg} \mathrm{ha}^{-1}+2 \mathrm{x} \mathrm{K}^{-B u i l d e r} 600 \mathrm{ml} \mathrm{ha}^{-1}\right)$.

Tabel 5. Rata-rata pertumbuhan jumlah anakan tanaman padi varietas IPB 9G pada perlakuan metode pemupukan kalium

\begin{tabular}{cccccccccc} 
& & \multicolumn{1}{c}{$\begin{array}{c}\text { Jumlah Anakan } \\
\text { (batang) }\end{array}$} \\
\cline { 2 - 11 } Taraf & 4 & 5 & 6 & 7 & 8 & 9 & 10 & 11 & 12
\end{tabular}




\begin{tabular}{ccrccccccc} 
Perlakuan & & & & & & & & \\
& MST & \multicolumn{1}{c}{ MST } & \multicolumn{1}{c}{ MST } & MST & MST & MST & MST & MST & MST \\
\hline P1 & 6.93 & 9.33 & 13.93 & 14.87 & 17.20 & 18.80 & 16.60 & $15.73 \mathrm{ab}$ & $16.27 \mathrm{a}$ \\
P2 & 7.07 & 9.40 & 12.40 & 13.13 & 13.13 & 16.40 & 15.27 & $14.40 \mathrm{~b}$ & $14.67 \mathrm{~b}$ \\
P3 & 7.60 & 11.40 & 15.67 & 17.00 & 17.07 & 18.27 & 16.93 & $17.07 \mathrm{a}$ & $17.20 \mathrm{a}$ \\
P4 & 7.47 & 9.40 & 13.00 & 14.13 & 15.73 & 16.53 & 16.53 & $16.13 \mathrm{ab}$ & $16.13 \mathrm{ab}$ \\
\hline Rata-rata & 7.27 & 9.88 & 13.75 & 14.78 & 15.78 & 17.50 & 16.33 & 15.83 & 16.07 \\
\hline
\end{tabular}

Keterangan: Angka yang diikuti huruf berbeda pada kolom yang sama berbeda nyata berdasarkan hasil Honestly Significant Difference (HSD) pada taraf $\alpha=0.05, \mathrm{P} 1\left(\mathrm{KCl} 100 \mathrm{~kg} \mathrm{ha}^{-1}\right), \mathrm{P} 2(\mathrm{KCl} 50$ $\left.\mathrm{kg} \mathrm{ha}^{-1}+\mathrm{KCl} 50 \mathrm{~kg} \mathrm{ha}^{-1}\right), \mathrm{P} 3\left(\mathrm{KCl} 50 \mathrm{~kg} \mathrm{ha}^{-1}+3 \mathrm{x} \mathrm{KNO}_{3} 22 \mathrm{~kg} \mathrm{ha}^{-1}\right), \mathrm{P} 4\left(\mathrm{KCl} 50 \mathrm{~kg} \mathrm{ha}^{-1}+2 \mathrm{x}\right.$ $\mathrm{K}$-Builder $600 \mathrm{ml} \mathrm{ha}^{-1}$ ).

Selain pupuk N, P, dan K yang diberikan juga mempengaruhi tinggi tanaman. Unsur hara $\mathrm{P}$ berfungsi dalam pembelahan sel, perkembangan akar, dan memperkuat batang dan $\mathrm{K}$ sangat penting dalam proses pembesaran batang. Pentingnya kalium dalam penambahan diameter batang berhubungan dengan fungsi kalium untuk meningkatkan kadar sklerenkim pada batang. Sklerenkim mempunyai fungsi memberi penebalan dan kekuatan pada jaringan batang sehingga tanaman lebih kuat atau tidak mudah rebah. Unsur hara $\mathrm{K}$ yang diserap tanaman pada fase vegetatif jauh lebih besar yang kemudian digunakan untuk pertumbuhan (Silahooy, 2008).

Perlakuan metode pemupukan kalium tidak memberikan pengaruh nyata terhadap Peubah tinggi tanaman saat 5 MST hingga 12 MST. Hal ini terjadi karena adanya fluktuasi curah hujan harian. Menurut BMKG $(2017,2018)$, pada bulan Desember 2017 sebanyak 11 hari tidak turun hujan dan Januari 2018 sebesar 6 hari tidak turun hujan. Pada saat hari tidak turun hujan bertepatan dengan waktu pemupukan sehingga kondisi tanah sempat mengalami kekeringan. Kekurangan air dapat menyebabkan terhambatnya pertumbuhan tanaman karena penyerapan hara dari dalam tanah oleh akar tanaman juga terhambat. Menurut Hardjowigeno (2007), unsur-unsur hara yang terlarut dalam air kemudian diserap oleh akar-akar tanaman dari larutan pemupukan.

\section{Jumlah Anakan}

Rata-rata jumlah anakan tanaman padi varietas IPB 9G dapat dilihat pada Tabel 5. Pertumbuhan jumlah anakan semua taraf perlakuan tidak berbeda nyata dari 4 sampai 10 MST. Pertumbuhan anakan berlangsung sejak munculnya anakan pertama sampai pembentukan anakan maksimum. Anakan terus berkembang sampai tanaman memasuki tahap pemanjangan batang dan fase primordia (Makarim dan Suhartatik, 2009). Anakan maksimum terjadi pada saat tanaman berumur 9 MST dan pada 10 MST hingga 12 MST pertumbuhan anakan mengalami fluktuasi (mengalami penurunan dan pertambahan anakan).
Berdasarkan hasil sidik ragam, perlakuan metode pemupukan kalium berpengaruh nyata terhadap peubah jumlah anakan pada 11 dan 12 MST. Berdasarkan hasil uji lanjut, pada 11 MST, taraf perlakuan P3 mampu meningkatkan jumlah anakan dibandingkan P2. Taraf perlakuan P3, P4, dan P1 memberikan pengaruh yang tidak berbeda nyata. Saat tanaman berumur 12 MST, taraf P1 dan P3 dapat meningkatkan jumlah anakan padi dibandingkan dengan P2.

Menurut Zubaidah dan Munir (2007), pada tanaman padi ketersediaan unsur hara $\mathrm{P}$ dan peningkatan serapan $\mathrm{P}$ oleh tanaman mengakibatkan jumlah anakan meningkat. Fosfor dibutuhkan tanaman dalam proses pembelahan sel dan sebagai energi dalam setiap proses metabolisme tanaman (Zulputra et al., 2014). Selain unsur hara $\mathrm{P}$, unsur hara $\mathrm{N}$ dan $\mathrm{K}$ juga mempengaruhi pertumbuhan anakan. Unsur hara $P$ berperan pada fase pertumbuhan tanaman dan berfungsi memacu pertumbuhan akar dan penambahan jumlah anakan (Abdulrachman et al., 2009).

Pada umur 4 sampai 10 MST perlakuan pemupukan tidak berpengaruh nyata. Hal ini diduga adanya anakan yang tumbuh dan ada yang mati pada fase vegetatif awal, sehingga pertumbuhan jumlah anakan belum stabil. Selain itu disebabkan kandungan $P$ tersedia pada lahan penelitian sedang dan ditambah pemupukan menjadikan kandungan $\mathrm{P}$ dalam tanah meningkat dapat menyebabkan ketersediaan unsur hara lain menjadi rendah. Menurut penelitian Zulputra et al. (2014), kandungan fosfor tersedia dalam jumlah yang banyak di larutan tanah akan menyebabkan ketersediaan unsur hara lain seperti hara makro (N dan $\mathrm{S}$ ) dan mikro (Zn, B dan $\mathrm{Mn}$ ) berkurang sehingga serapan hara menjadi tidak seimbang dan pembentukan anakan terganggu.

\section{Bagan Warna Daun}

Rata-rata skor bagan warna daun tanaman padi gogo varietas IPB 9G dapat dilihat pada Tabel 6. Skor bagan warna daun menunjukkan tingkat kehijauan warna daun yang menunjukkan 
kadar klorofil daun. Skor Bagan Warna Daun (BWD) dapat menjadi pedoman pemupukan nitrogen pada tanaman padi. Perlakuan metode pemupukan kalium pada peubah Skor BWD berpengaruh nyata hanya pada 5 MST. Taraf perlakuan P3 mampu menghasilkan skor BWD lebih tinggi dibandingkan P1 dan sebanding dengan $\mathrm{P} 2$ dan $\mathrm{P} 4$. Penggunaan $\mathrm{KNO}_{3}$ dalam taraf $\mathrm{P} 3$ selain menambah unsur hara $\mathrm{K}$ juga ikut menyumbang unsur hara N. Pupuk $\mathrm{KNO}_{3}$ memiliki kadar $\mathrm{K}_{2} \mathrm{O}$ sebesar $46 \%$ dan $\mathrm{NO}_{3}$ sebesar $13 \%$.

Menurut Permentan Nomor 40/Permentan/OT.140/4/2007, semakin rendah skala BWD menunjukkan semakin sedikit ketersediaan $\mathrm{N}$ di tanah dan hal ini mengakibatkan semakin besar jumlah pupuk $\mathrm{N}$ yang perlu diberikan. Semakin pucat warna daun, maka menunjukkan semakin rendah skor BWD. Nilai kritis untuk pemupukan $\mathrm{N}$ pada tanaman padi adalah 4. BWD skala 4 cenderung memberikan nilai efisiensi agronomi tertinggi (Erythrina, 2016). Pada saat tanaman berumur 10 dan 11 MST menunjukkan skor BWD yaitu 4 yang berarti tanaman padi sudah memiliki hara $\mathrm{N}$ yang cukup sehingga tidak perlu lagi dipupuk.

Anakan Total, Anakan Produktif, Anakan Tidak Produktif, dan Tinggi Tanaman Panen
Pengamatan terhadap jumlah anakan total, jumlah anakan produktif, jumlah anakan tidak produktif, tinggi tanaman saat panen, dan kerapatan stomata dilakukan menjelang panen. Jumlah anakan pada fase pertumbuhan akhir (12 MST) berbeda ketika tanaman akan dipanen. Berdasarkan Tabel 7, perlakuan metode pemupukan kalium memberikan pengaruh nyata terhadap jumlah anakan total dan sangat nyata pada jumlah anakan produktif, jumlah anakan tidak produktif, tinggi tanaman panen, dan kerapatan stomata.

Berdasarkan hasil uji lanjut, taraf perlakuan P3 dan P4 dapat meningkatkan jumlah anakan total dibandingkan dengan $\mathrm{P} 2$, tetapi tidak berbeda nyata dengan P1. Pada peubah jumlah anakan produktif, taraf perlakuan P3 menghasilkan anakan produktif lebih tinggi dibandingkan dengan P2, tetapi tidak berbeda nyata dengan P4. Anakan produktif yang dihasilkan pada deskripsi varietas berjumlah 11 batang. Taraf pemupukan P3 mampu menurunkan jumlah anakan tidak produktif pada tanaman dibandingkan taraf yang lain. Hasil analisis statistik menunjukkan bahwa metode pemupukan kalium berpengaruh sangat nyata pada tinggi tanaman saat panen dan kerapatan stomata. Tinggi tanaman saat panen menunjukkan perbandingan tinggi tanaman dengan panjang malai.

Tabel 6. Rata-rata skor bagan warna daun tanaman padi varietas IPB 9G pada perlakuan metode pemupukan kalium

\begin{tabular}{|c|c|c|c|c|c|c|c|c|c|}
\hline \multirow{3}{*}{ Taraf Perlakuan } & \multicolumn{9}{|c|}{ Bagan Warna Daun (skor) } \\
\hline & 4 & 5 & 6 & 7 & 8 & 9 & 10 & 11 & 12 \\
\hline & MST & MST & MST & MST & MST & MST & MST & MST & MST \\
\hline P1 & 2.7 & $2.8 \mathrm{~b}$ & 3.1 & 3.4 & 3.7 & 3.7 & 4.0 & 4.0 & 4.0 \\
\hline $\mathrm{P} 2$ & 2.6 & $2.9 \mathrm{ab}$ & 3.0 & 3.3 & 3.2 & 3.4 & 4.0 & 4.0 & 3.8 \\
\hline P3 & 2.9 & $3.5 \mathrm{a}$ & 3.4 & 3.8 & 3.7 & 3.9 & 4.0 & 4.0 & 4.0 \\
\hline P4 & 2.7 & $3.0 \mathrm{ab}$ & 3.1 & 3.4 & 3.6 & 3.8 & 4.0 & 4.0 & 4.0 \\
\hline Rata-rata & 2.7 & 3.0 & 3.2 & 3.5 & 3.5 & 3.7 & 4.0 & 4.0 & 3.9 \\
\hline
\end{tabular}

Keterangan: Angka yang diikuti huruf berbeda pada kolom yang sama berbeda nyata berdasarkan hasil Honestly Significant Difference (HSD) pada taraf $\alpha=0.05, \mathrm{P} 1\left(\mathrm{KCl} 100 \mathrm{~kg} \mathrm{ha}^{-1}\right), \mathrm{P} 2(\mathrm{KCl} 50 \mathrm{~kg}$ $\left.\mathrm{ha}^{-1}+\mathrm{KCl} 50 \mathrm{~kg} \mathrm{ha}^{-1}\right), \mathrm{P} 3\left(\mathrm{KCl} 50 \mathrm{~kg} \mathrm{ha}^{-1}+3 \mathrm{x} \mathrm{KNO}_{3} 22 \mathrm{~kg} \mathrm{ha}^{-1}\right), \mathrm{P} 4\left(\mathrm{KCl} 50 \mathrm{~kg} \mathrm{ha}^{-1}+2 \mathrm{x} \mathrm{K}-\right.$ Builder $600 \mathrm{ml} \mathrm{ha}^{-1}$ ).

Tabel 7. Pengaruh metode pemupukan kalium terhadap beberapa peubah pada saat panen tanaman padi

\begin{tabular}{cccccc}
\hline Taraf Perlakuan & $\begin{array}{c}\text { Jumlah Anakan } \\
\text { Total }\end{array}$ & $\begin{array}{c}\text { Jumlah Anakan } \\
\text { Produktif }\end{array}$ & $\begin{array}{c}\text { Jumlah Anakan } \\
\text { Tidak Produktif }\end{array}$ & $\begin{array}{c}\text { Tinggi } \\
\text { Tanaman } \\
\text { Panen }(\mathrm{cm})\end{array}$ & $\begin{array}{c}\text { Kerapatan } \\
\text { Stomata } \\
\left(\text { sel per cm }{ }^{2}\right)\end{array}$ \\
\hline P1 & $15.86 \mathrm{ab}$ & $14.86 \mathrm{bc}$ & $1.00 \mathrm{a}$ & $88.89 \mathrm{a}$ & $0.36 \mathrm{a}$ \\
P2 & $14.26 \mathrm{~b}$ & $13.13 \mathrm{c}$ & $1.06 \mathrm{a}$ & $77.04 \mathrm{~b}$ & $0.37 \mathrm{a}$ \\
P3 & $16.86 \mathrm{a}$ & $16.86 \mathrm{a}$ & $0.00 \mathrm{~b}$ & $90.73 \mathrm{a}$ & $0.23 \mathrm{~b}$ \\
P4 & $16.20 \mathrm{a}$ & $15.46 \mathrm{ab}$ & $0.73 \mathrm{a}$ & $88.94 \mathrm{a}$ & $0.22 \mathrm{~b}$ \\
\hline
\end{tabular}

Keterangan: Angka yang diikuti huruf berbeda pada kolom yang sama berbeda nyata berdasarkan hasil Honestly Significant Difference (HSD) pada taraf $\alpha=0.05, \mathrm{P} 1\left(\mathrm{KCl} 100 \mathrm{~kg} \mathrm{ha}^{-1}\right), \mathrm{P} 2(\mathrm{KCl} 50 \mathrm{~kg}$ $\left.\mathrm{ha}^{-1}+\mathrm{KCl} 50 \mathrm{~kg} \mathrm{ha}^{-1}\right), \mathrm{P} 3\left(\mathrm{KCl} 50 \mathrm{~kg} \mathrm{ha}^{-1}+3 \mathrm{x} \mathrm{KNO}_{3} 22 \mathrm{~kg} \mathrm{ha}^{-1}\right), \mathrm{P} 4\left(\mathrm{KCl} 50 \mathrm{~kg} \mathrm{ha}^{-1}+2 \mathrm{x} \mathrm{K}-\right.$ Builder $600 \mathrm{ml} \mathrm{ha}^{-1}$ ). 
Berdasarkan hasil, perbandingan tinggi tanaman dengan panjang malai yaitu 3:1 untuk semua taraf perlakuan. Taraf perlakuan P3, P4, dan P1 memberikan pengaruh yang sama terhadap peubah tinggi tanaman panen dan berbeda nyata dengan $\mathrm{P} 2$.

\section{Pengaruh Metode Pemupukan Kalium Terhadap Komponen Hasil Tanaman}

Peubah komponen hasil diamati setelah panen meliputi panjang malai, jumlah gabah total, jumlah gabah isi, jumlah gabah hampa, persentase gabah isi, bobot 1000 butir, bobot gabah per rumpun, bobot gabah ubinan, produktivitas GKP, dan produktivitas GKG.

\section{Panjang Malai, Gabah Total, Gabah Isi, Gabah Hampa, Persentase Gabah Isi, dan Bobot 1000 Butir Gabah}

Panen dilakukan saat tanaman berumur 126 HST, berbeda pada deskripsi varietas tentang umur panen 113 HSS. Hal ini karena saat tanaman berumur $100 \mathrm{MST}$, batang padi masih hijau dan pemasakan bulir gabah belum sempurna sehingga masih membutuhkan waktu untuk panen optimum. Berdasarkan Tabel 8, metode pemupukan kalium tidak memberikan pengaruh nyata pada jumlah gabah total, jumlah gabah isi, jumlah gabah hampa per malai, persentase gabah isi, dan bobot 1000 butir gabah. Hal ini diduga karena curah hujan dan hama pertanaman.

Pada saat tanaman memasuki fase generatif (umur 15 MST), curah hujan yang tinggi saat pengisisan biji sehingga tidak memberikan pengaruh tehadap pemupukan kalium. Curah hujan yang tinggi menyebabkan terganggunya fotosintesis akibat kekurangan cahaya, selain itu dapat menyebabkan terjadi pencucian hara kalium oleh hujan akan mengakibatkan semakin rendah kalium di dalam tanah, sedangkan kalium diserap dalam jumlah banyak pada fase pengisian gabah saat tanaman berumur 80 HST (Wihardjaka, 2002). Menurut Lakudzala (2013), unsur hara K berkaitan dengan transportasi air, nutrisi, dan karbohidrat pada jaringan tanaman. Karbohidrat yang disimpan dalam jaringan batang dan daun kemudian diubah menjadi gula, lalu diangkut ke jaringan biji sehingga dapat menambah berat biji.

Tabel 8. Pengaruh metode pemupukan kalium terhadap gabah panen

\begin{tabular}{ccccccc}
\hline $\begin{array}{c}\text { Taraf } \\
\text { Perlakuan }\end{array}$ & $\begin{array}{c}\text { Panjang Malai } \\
(\mathrm{cm})\end{array}$ & $\begin{array}{c}\sum \text { Gabah Total } / \\
\text { Malai (biji) }\end{array}$ & $\begin{array}{c}\sum \text { Gabah Isi / } \\
\text { Malai (biji) }\end{array}$ & $\begin{array}{c}\text { K Gabah } \\
\text { Hampa / } \\
\text { Malai (biji) }\end{array}$ & $\begin{array}{c}\text { Persentase } \\
\text { Gabah Isi (\%) }\end{array}$ & $\begin{array}{c}\text { Bobot } \\
1000 \text { Butir } \\
(\mathrm{g})\end{array}$ \\
\hline P1 & $28.97 \mathrm{ab}$ & 213.75 & 152.25 & 61.50 & 70.09 & 26.16 \\
P2 & $28.25 \mathrm{~b}$ & 218.50 & 134.08 & 84.42 & 61.36 & 26.18 \\
P3 & $30.45 \mathrm{a}$ & 277.83 & 198.67 & 79.17 & 71.00 & 26.96 \\
P4 & $30.70 \mathrm{a}$ & 269.83 & 211.50 & 58.33 & 78.75 & 26.55 \\
\hline
\end{tabular}

Keterangan: Angka yang diikuti huruf berbeda pada kolom yang sama berbeda nyata berdasarkan hasil Honestly Significant Difference (HSD) pada taraf $\alpha=0.05, \mathrm{P} 1\left(\mathrm{KCl} 100 \mathrm{~kg} \mathrm{ha}^{-1}\right), \mathrm{P} 2\left(\mathrm{KCl} 50 \mathrm{~kg} \mathrm{ha}^{-1}+\mathrm{KCl} 50 \mathrm{~kg}\right.$ $\left.\mathrm{ha}^{-1}\right), \mathrm{P} 3\left(\mathrm{KCl} 50 \mathrm{~kg} \mathrm{ha}^{-1}+3 \mathrm{x} \mathrm{KNO}_{3} 22 \mathrm{~kg} \mathrm{ha}^{-1}\right), \mathrm{P} 4\left(\mathrm{KCl} 50 \mathrm{~kg} \mathrm{ha}^{-1}+2 \mathrm{x} \mathrm{K}^{-B u i l d e r} 600 \mathrm{ml} \mathrm{ha}^{-1}\right)$.

Serangan hama mengakibatkan bulir menjadi hampa. Hama walang sangit (Leptocorisa oratorius) yang mulai menyerang tanaman pada saat masak susu dan hama burung bondol yang dapat masuk ke pertanaman walaupun telah dipasang jaring. Hama dan penyakit yang menyerang menyebabkan bobot gabah per rumpun tanaman rendah dan dibuktikan dengan banyaknya gabah hampa dengan ciri-ciri gabah seperti bintik-bintik coklat pada gabah akibat penghisapan cairan dari hama tersebut (Purnomo, 2013). Burung bondol juga menghisap cairan padi seperti halnya walang sangit. Hama ini bukan saja dapat menurunkan hasil tetapi juga menurunkan kualitas gabah.

Perlakuan metode pemupukan berpengaruh nyata terhadap panjang malai. Taraf perlakuan P4 dan P3 mampu meningkatkan panjang malai dibandingkan dengan P2. Panjang malai menentukan jumlah gabah yang dihasilkan. Semakin panjang malai maka jumlah gabah yang dihasilkan semakin banyak. Jumlah gabah per malai yang banyak diperoleh dari malai-malai yang berukuran panjang (Riyanto et al., 2012).

Bobot Gabah Per Rumpun, Bobot Gabah Ubinan, Produktivitas GKP, dan Produktivitas

Hasil analisis ragam menunjukkan perlakuan metode pemupukan kalium tidak berpengaruh nyata pada peubah bobot gabah pe rumpun. Respon pemupukan kalium terhadap pendugaan bobot gabah ubinan, produktivitas GKP, dan produktivitas GKG berpengaruh sangat nyata terhadap hasil. Pada saat panen diperoleh kadar air GKP rata-rata berkisar $17.06-18.86 \%$. Kadar air gabah saat panen menunjukkan berat gabah. Semakin tinggi kadar air saat dipanen (GKP) akan menghasilkan berat gabah yang lebih rendah setelah dikeringkan (GKG).

Kebutuhan kalium untuk tanaman padi sebesar $122.4 \mathrm{~kg}$ setara dengan $235.4 \mathrm{~kg} \mathrm{KCl}$ atau $141.24 \mathrm{~kg} \mathrm{~K}_{2} \mathrm{O}$ (Subandi, 2013). Total $\mathrm{K}_{2} \mathrm{O}$ yang 
diberikan pada taraf P1, P2, P3, dan P4 masingmasing sebesar $60 \mathrm{~kg}, 60 \mathrm{~kg}, 60.6 \mathrm{~kg}$, dan 30.84 $\mathrm{kg}$. Kalium yang terkandung dalam K-Builder adalah kalium karbonat yang mengandung $68 \%$ $\mathrm{K}_{2} \mathrm{O}$ sehingga dalam $600 \mathrm{ml} \mathrm{ha}^{-1} \mathrm{~K}-\mathrm{Builder}$ terkandung $408 \mathrm{ml} \mathrm{ha}^{-1} \mathrm{~K}_{2} \mathrm{O}$, besaran ini setara dengan $420.24 \mathrm{~g} \mathrm{ha}^{-1}$ atau $0.42 \mathrm{~kg} \mathrm{ha}^{-1} \mathrm{~K} 2 \mathrm{O}$ (1 $\mathrm{ml}=1.03 \mathrm{~g}$ ) (Widyatmoko, 2016). Penggunaan pupuk kalium pada taraf $\mathrm{P} 1, \mathrm{P} 2$, dan $\mathrm{P} 3$ diberikan melalui tanah dan pada taraf P4 diberikan melalui daun. Menurut Hardjowigeno (2007), pemberian pupuk melalui daun menyebabkan hampir semua unsur hara lebih cepat dan mudah diserap oleh tanaman. Pemberian pupuk lewat tanah tidak semua unsur hara dapat diserap akar.

Tabel 9. Pengaruh metode pemupukan kalium terhadap dugaan produktivitas tanaman padi

\begin{tabular}{|c|c|c|c|c|}
\hline $\begin{array}{c}\text { Taraf } \\
\text { Perlakuan }\end{array}$ & $\begin{array}{l}\text { Bobot } \\
\text { Gabah } \\
\text { per } \\
\text { Rumpun } \\
\text { (g) }\end{array}$ & $\begin{array}{l}\text { Bobot } \\
\text { Gabah } \\
\text { Ubinan } \\
(\mathrm{kg})\end{array}$ & $\begin{array}{l}\text { Produktivitas } \\
\text { GKP (ton ha } \\
\text { 1) }\end{array}$ & $\begin{array}{c}\text { S Produktivitas } \\
\text { GKG (ton ha } \\
1 \text { ) }\end{array}$ \\
\hline $\mathrm{P} 1$ & 47.06 & $1.96 \mathrm{a}$ & $4.45 a$ & $4.25 \mathrm{a}$ \\
\hline $\mathrm{P} 2$ & 39.86 & $1.16 \mathrm{~b}$ & $2.64 b$ & $2.55 \mathrm{~b}$ \\
\hline P3 & 40.06 & $2.20 \mathrm{a}$ & $4.98 \mathrm{a}$ & $4.70 \mathrm{a}$ \\
\hline P4 & 43.20 & $2.23 \mathrm{a}$ & $5.06 \mathrm{a}$ & $4.77 \mathrm{a}$ \\
\hline
\end{tabular}

Keterangan: Angka yang diikuti huruf berbeda pada kolom yang sama berbeda nyata berdasarkan hasil Honestly Significant Difference (HSD) pada taraf $\alpha=0.05, \mathrm{P} 1$ $\left(\mathrm{KCl} 100 \mathrm{~kg} \mathrm{ha}^{-1}\right), \mathrm{P} 2\left(\mathrm{KCl} 50 \mathrm{~kg} \mathrm{ha}^{-1}+\right.$ $\left.\mathrm{KCl} 50 \mathrm{~kg} \mathrm{ha}^{-1}\right), \mathrm{P} 3\left(\mathrm{KCl} 50 \mathrm{~kg} \mathrm{ha}^{-1}+3 \mathrm{x}\right.$ $\left.\mathrm{KNO}_{3} 22 \mathrm{~kg} \mathrm{ha}^{-1}\right), \mathrm{P} 4\left(\mathrm{KCl} 50 \mathrm{~kg} \mathrm{ha}^{-1}+2\right.$ $\mathrm{x}$ K-Builder $600 \mathrm{ml} \mathrm{ha}^{-1}$ ), GKP: gabah kering panen, GKG: gabah kering giling.

Bobot gabah ubinan menunjukkan besarnya produktivitas tanaman. Ubinan yang digunakan berukuran $2.1 \mathrm{~m}$ x $2.1 \mathrm{~m}$. Semakin besar bobot gabah ubinan maka semakin besar produktivitas yang dihasilkan. Berdasarkan Tabel 9, taraf perlakuan P1, P3, dan P4 mampu meningkatkan peubah bobot gabah ubinan, produktivitas GKP, dan produktivitas GKG dibandingkan dengan $\mathrm{P} 2$. Produktivitas GKG yang dihasilkan P1, P3, dan P4 belum mampu mencapai rata-rata hasil pada deskripsi varietas sebesar 6.09 ton $\mathrm{ha}^{-1}$.

Taraf perlakuan P2 menunjukkan bobot gabah ubinan, produktivitas GKP, dan produktivitas GKG paling rendah dibandingkan taraf perlakuan yang lain. Hal ini diduga pemupukan kalium diberikan pada dua waktu yang berjauhan yaitu 0 MST dan 8 MST.
Pemberian kalium pada taraf perlakuan P2 diduga terlambat diberikan sehingga saat tanaman membutuhkan, kalium yang ada tidak cukup tersedia untuk pengisian biji. Pemupukan kalium yang diberikan dalam tanah bisa jadi terjebak dalam mineral tanah sehingga tidak dapat terserap oleh tanaman. Selain itu, pemberian pupuk K melalui tanah memiliki banyak hambatan antara lain pencucian oleh air dan erosi tanah. Unsur $\mathrm{K}^{+}$ bersifat dinamis dalam tanah sehingga mudah tercuci. Unsur kalium merupakan unsur yang mudah bergerak, dugaan lain tanaman pada taraf perlakuan P2 melakukan translokasi unsur hara, kalium dipindahkan dari satu organ ke organ lain tanaman yang lebih membutuhkan (Novizan, 2002). Menurut penelitian Ispandi dan Munip (2004), Kadar K dalam tanaman tinggi bila pupuk $\mathrm{K}$ diberikan satu kali, dan bila diberikan dua kali maka kadar $\mathrm{K}$ dalam tanaman tidak banyak berubah.

Dilihat dari segi ekonomi (Tabel 10), penggunakan pupuk kalium pada taraf perlakuan $\mathrm{P} 1$ dengan satu kali aplikasi pupuk $\mathrm{KCl}$ dosis 100 $\mathrm{kg} \mathrm{ha}{ }^{-1}$ menghasilkan produktivitas yang tidak berbeda nyata dengan P3 dan P4. Harga pupuk $\mathrm{KCl}$ per kg sebesar Rp 14 000,00. Untuk luasan 1 ha, artinya membutuhkan anggaran untuk pupuk $\mathrm{KCl}$ sebesar Rp 1400000 dengan biaya tenaga kerja pupuk satu kali aplikasi.

Tabel 10. Analisis biaya perlakuan metode pemupukan kalium

\begin{tabular}{cccc}
\hline $\begin{array}{c}\text { Taraf } \\
\text { Perlakuan }\end{array}$ & $\begin{array}{c}\text { Biaya Pupuk } \\
\text { Kalium (Rp } \\
\left.\text { ha }^{-1}\right)\end{array}$ & $\begin{array}{c}\text { Aplikasi } \\
\text { Pemupukan } \\
\text { Kalium }\end{array}$ & $\begin{array}{c}\text { Hasil } \\
\text { Produktivitas } \\
\text { GKG } \\
\left(\text { ton ha }^{-1}\right)\end{array}$ \\
\hline P1 & 1400000 & 1 kali & 4.25 \\
P2 & 1400000 & $2 \mathrm{kali}$ & 2.55 \\
P3 & 2215000 & 4 kali & 4.70 \\
P4 & 791200 & $3 \mathrm{kali}$ & 4.77 \\
\hline
\end{tabular}

Taraf perlakuan P2 menghasilkan produktivitas GKG paling rendah diantara taraf perlakuan yang lain dengan biaya pupuk Rp 1400 000,00 dan biaya tenaga kerja dua kali aplikasi pupuk. Taraf perlakuan P3 menggunakan aplikasi

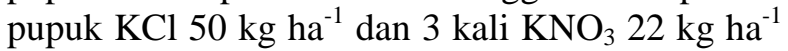
dengan anggaran pembelian pupuk $\mathrm{KCl}$ sebesar Rp 700,000 dan $\mathrm{KNO}_{3} \mathrm{Rp}$ 2,145,000. Taraf perlakuan P3 membutuhkan biaya yang sangat besar dibandingkan taraf yang lain untuk pembelian

Tabel 11. Analisis korelasi beberapa peubah pertumbuhan tanaman dengan komponen hasil

\begin{tabular}{|c|c|c|c|c|c|c|c|c|c|}
\hline Korelasi & AT & $\mathrm{JP}$ & JTP & TTP & $\mathrm{KS}$ & PM & GT & GI & $\mathrm{GH}$ \\
\hline $\mathrm{JP}$ & $0.982 *$ & & & & & & & & \\
\hline JTP & -0.786 & -0.888 & & & & & & & \\
\hline TTP & $0.967 *$ & 0.903 & -0.607 & & & & & & \\
\hline $\mathrm{KS}$ & -0.784 & -0.811 & 0.759 & -0.661 & & & & & \\
\hline PM & 0.868 & 0.862 & -0.720 & 0.789 & $-0.979 *$ & & & & \\
\hline GT & 0.753 & 0.813 & -0.841 & 0.593 & $-0.983^{*}$ & 0.935 & & & \\
\hline
\end{tabular}




\begin{tabular}{crrrrrrrrr} 
GI & 0.829 & 0.823 & -0.688 & 0.748 & $-0.984^{*}$ & $0.997^{* *}$ & 0.938 & & \\
GH & -0.414 & -0.24 & -0.219 & -0.600 & 0.258 & -0.421 & -0.081 & -0.423 & \\
PI & 0.758 & 0.665 & -0.339 & 0.801 & -0.788 & 0.880 & 0.665 & 0.884 & -0.798 \\
BO & 0.784 & 0.879 & -0.978 & 0.599 & -0.870 & 0.820 & 0.935 & 0.801 & 0.140 \\
RUM & 0.182 & 0.004 & 0.436 & 0.428 & 0.249 & -0.051 & -0.398 & -0.074 & -0.824 \\
UBIN & $0.962^{*}$ & 0.902 & -0.615 & $0.976^{*}$ & -0.789 & 0.895 & 0.712 & 0.868 & -0.634 \\
PKP & $0.961^{*}$ & 0.899 & -0.611 & $0.975^{*}$ & -0.788 & 0.894 & 0.709 & 0.868 & -0.638 \\
PKG & $0.96^{*}$ & 0.896 & -0.603 & $0.978^{*}$ & -0.776 & 0.886 & 0.697 & 0.858 & -0.644 \\
\hline Korelasi & PI & \multicolumn{1}{c}{ BO } & RUM & UBIN & PGKP & & & & \\
\hline BO & 0.457 & & & & & & & & \\
RUM & 0.373 & -0.468 & & & & & & & \\
UBIN & 0.900 & 0.653 & 0.341 & & & & & & \\
PKP & 0.902 & 0.649 & 0.345 & $1.00^{* *}$ & & & & \\
PKG & 0.899 & 0.639 & 0.360 & $1.00^{* *}$ & $1.00^{* *}$ & & & \\
\hline
\end{tabular}

Keterangan: tn : berkorelasi tidak nyata pada taraf $\alpha=5 \%, *$ : berkorelasi nyata pada taraf $\alpha=5 \%, * *$ : berkorelasi sangat nyata pada taraf $\alpha=5 \%$. Peubah pengamatan (AT) anakan total, (JP) jumlah anakan produktif, (JTP) jumlah anakan tidak produktif, (TP) tinggi tanaman panen, (KS) kerapatan stomata, (PM) panjang malai, (G) Jumlah gabah total, (GI) jumlah gabah isi, (GH) jumlah gabah hampa, (PI) persentase gabah isi, (BO) bobot 1000 butir, (RUM) bobot gabah per rumpun, (UBIN) bobot gabah ubinan, (PKP) produktivitas GKP, dan (PKG) produktivitas GKG.

pupuk $\mathrm{KNO}_{3}$ dan biaya tenaga kerja lebih besar untuk aplikasi pupuk. Taraf perlakuan P4 diberikan pupuk KCL $50 \mathrm{~kg} \mathrm{ha}^{-1}$ dan 2 kali aplikasi K-Builder $600 \mathrm{ml} \mathrm{ha}^{-1}$, total biaya untuk pembelian $\mathrm{KCl} \mathrm{Rp} 700,000$ dan K-Builder Rp 91,200.

Taraf perlakuan P4 memberikan hasil yang sebanding dengan P1 dan P3, tetapi dari segi sumber pupuk kalium berupa K-Builder yang digunakan merupakan produk yang dihasilkan oleh Growth Product Company, Singapura dan belum beredar bebas sehingga jarang ditemui di Indonesia. Jika diaplikasikan untuk petani, lebih baik menggunakan taraf perlakuan P1 karena selain hasil yang diperoleh sebanding dengan P3 dan P4, biaya yang digunakan untuk pembelian pupuk dan tenaga kerja lebih rendah.

\section{Analisis Korelasi antar Peubah Pengamatan}

Korelasi antar beberapa peubah pertumbuhan dengan komponen hasil dapat dilihat pada Tabel 11. Anakan total berkorelasi positif nyata dengan jumlah anakan produktif. Hal ini berarti semakin banyak jumlah anakan total maka semakin banyak anakan produktif yang dihasilkan. Hasil tersebut sejalan dengan pernyataan Riyani et al. ( 2013), pembentukan jumlah anakan produktif berkaitan dengan jumlah anakan maksimum. Semakin banyak jumlah anakan maksimum maka jumlah anakan produktif yang dihasilkan lebih banyak.

Tinggi tanaman panen berkorelasi positif nyata dengan anakan total. Peubah panjang malai, jumlah gabah total, dan jumlah gabah isi berkorelasi negatif nyata terhadap kerapatan stomata. Hal ini menunjukkan bahwa jika nilai kerapatan stomata yang dihasilkan semakin rendah, maka semakin tinggi panjang malai, jumlah gabah total, dan gabah isi yang dihasilkan.
Jumlah gabah isi juga berkorelasi positif sangat nyata terhadap panjang malai. Hal ini sesuai dengan pernyataan Wibowo (2010), malai yang panjang menghasilkan buku-buku yang terus membentuk cabang primer dan cabang sekunder. Jumlah gabah per malai yang banyak akan menghasilkan gabah isi yang banyak juga. Peubah jumlah gabah hampa, persentase gabah isi, bobot 1000 butir, dan bobot gabah perumpun berkorelasi tidak nyata terhadap peubah yang lain.

Bobot gabah ubinan berkorelasi positif nyata terhadap anakan total dan tinggi tanaman panen. Pernyataan Rohaeni dan Permadi (2012) menunjukkan bobot gabah ubinan berkorelasi positif dengan tinggi tanaman panen. Produktivitas GKP berkorelasi positif nyata dengan anakan total dan tinggi tanaman panen serta berkorelasi positif sangat nyata dengan bobot gabah ubinan. Produktivitas GKG berkorelasi positif nyata dengan anakan total dan tinggi tanaman panen serta berkorelasi positif sangat nyata dengan bobot gabah ubinan dan produktivitas GKP. Hasil tersebut sesuai dengan pernyataan Hambali dan Lubis (2015), konversi produktivitas berkorelasi positif sangat nyata terhadap bobot gabah ubinan.

\section{KESIMPULAN DAN SARAN}

Perlakuan metode pemupukan kalium memberikan pengaruh lebih baik terhadap peubah jumlah anakan total, jumlah anakan produktif, jumlah anakan tidak produktif, tinggi tanaman panen, panjang malai, bobot gabah ubinan, produktivitas GKP dan produktivitas GKG. Metode pemupukan kalium P1, P3, dan P4 mampu meningkatkan bobot gabah ubinan, produktivitas GKP, dan produktivitas GKG. 


\section{DAFTAR PUSTAKA}

Abdulrachman, S., H. Sembiring, Suyamto. 2009. Pemupukan Tanaman Padi. Balai Besar Penelitian Tanaman Padi, Subang.

[BMKG] Badan Meteorologi Klimatologi dan Geofisika. 2017. Data Iklim. Stasiun Klimatologi Bogor.

[BMKG] Badan Meteorologi Klimatologi dan Geofisika. 2018. Data Iklim. Stasiun Klimatologi Bogor.

[BPS] Badan Pusat Statistik. 2014. Statistik Indonesia. Badan Pusat Statistik, Jakarta.

[BPS] Badan Pusat Statistik. 2017. Statistik Indonesia. Badan Pusat Statistik, Jakarta.

Dobermann, A., T. Fairhurst. 2000. Rice : Nutrient Disorders and Nutrient Managemant. Potash and Phosphate Institute of Canada (PPIC) and International Rice Research Institute (IRRI), Los Banos.

Erythrina. 2016. Bagan warna daun: alat untuk meningkatkan efisiensi pemupukan nitrogen pada tanaman padi. J. Litbang Pertanian. 35(1):1-10.

Hambali, A., I. Lubis. 2015. Evaluasi produktivitas beberapa varietas padi. Bul. Agrohorti. 3(2):137-145.

Hardjowigeno, S. 2007. Ilmu Tanah. Akademika Pressindo, Jakarta.

Ispandi, A., A. Munip. 2004. Efektivitas pupuk NPK dan frekuensi pemberian pupuk $\mathrm{k}$ dalam meningkatkan serapan hara dan produksi kacangtanah di lahan kering alfisol. J. Ilmu Pertanian. 11(2):11-24.

Lakudzala, D. D.2013. Potassium response in some Malawi soils. International Letter of Chemistry, Physics and Astronomy. 8(2):175-181.

Makarim, A.K., E. Suhartatik. 2009. Morfologi dan Fisiologi Tanaman Padi (Padi Buku 1). Balai Besar Penelitian Tanaman Padi. Subang.

Novizan. 2002. Petunjuk Pemupukan yang Efektif. Agromedia, Jakarta.

Nursyamsi, D., Suprihati. 2005. Sifat-sifat kimia dan mineralogi tanah serta kaitannya dengan kebutuhan pupuk untuk padi (Oryza sativa), jagung (Zea mays), dan kedelai (Glycine max). Bul. Agron. 33(3):40-47.
[PERMENTAN] Peraturan Menteri Pertanian. Rekomendasi Pemupukan N, P, Dan K Pada Padi Sawah Spesifik Lokasi. NOMOR 40/Permentan/OT.140/4/2007.

Purnomo, S. 2013. Populasi walang sangit (Leptocorisa oratorius Fabricius) di Kecamatan Sabak Auh Kabupaten Siak Provinsi Riau pada tanaman padi masa tanam musim penghujan. Skripsi. Universitas Islam Negeri Sultan Syarif Kasim Riau. Pekanbaru.

Puspadewi, S., W. sutari, Kusumiyati. 2016. Pengaruh konsentrasi pupuk organik cair (POC) dan dosis pupuk N, P, K terhadap pertumbuhan dan hasil tanaman jagung manis (Zea mays L. var Rugosa Bonaf) kultivar Talenta. J. Kultivasi.15(3): 208216.

Riyani, R., Radian. S. Budi. 2013. Pengaruh berbagai pupuk organik terhadap pertumbuhan dan hasil padi di lahan pasang surut. J. Sains. 1-11.

Riyanto, A., T. Widiatmoko, B. Hartanto. Korelasi antar komponen hasil dan hasil pada padi genotip F5 keturunan persilangan G39 x Ciherang. Dalam Riyanto, A., T. Widiatmoko, B. Hartanto (Eds). Prosiding Seminar Nasional Pengembangan Sumber Daya Pedesaan dan Kearifan Lokal Berkelanjutan II. Purwokerto, 27-28 November 2012.

Rohaeni, W. R. , K. Permadi. 2012. Analisis sidik lintas beberapa karakter komponen hasil terhadap daya hasil padi sawah pada aplikasi agrisimba. J. Agrotrop. 2(2):185-190.

Sahardi, Herniwati, F. Djufry. 2014. Produktivitas tanaman dan kelayakan finansial padi di lahan sawah bukaan baru dengan berbagai pemupukan di Sulawesi Selatan. J. Pengkajian dan Pengembangan Teknologi Pertanian. 17(3):187-196.

Silahooy.2008. Efek pupuk $\mathrm{KCl}$ dan SP-36 terhadap kalium tersedia,serapan kalium dan hasil kacang tanah (Arachis hypogaea L. ) pada tanah Brunizem. Bul. Agron. 36(2):126-132.

Subandi. 2013. Peran dan pengelolaan hara kalium untuk produksi pangan di Indonesia. J. Pengembangan Inovasi Pertanian . 6(1):1-10.

Suhendrata, T., S. Budiyanto. 2012. Peningkatan produktivitas padi gogo dan pendapatan petani lahan kering melalui perubahan 
penerapan sistem tanam di Kabupaten Banjarnegara. Dalam Suhendrata, T., S. Budiyanto (Eds). Prosiding Seminar Nasional Kedaulatan Pangan dan Energi. Madura, Juni 2012.

Tsalitsan, Z.B. 2017. Pertumbuhan dan produksi sepuluh genotipe kedelai (Glycine Max L. Merril) di Tanah Latosol Dramaga Bogor. [Skripsi]. Institut Pertanian Bogor, Bogor.

Wibowo, P. 2010. Pertumbuhan dan produktivitas galur harapan padi (Oryza sativa L.) hibrida di Desa Ketaon Kecamatan Banyudono Boyolali. [Skripsi]. Universitas Sebelas Maret, Surakarta.

Widyatmoko, R. F. 2016. Pengaruh aplikasi pupuk dolomit dan kalium terhadap produksi kacang tanah (Arachis hypogaea L.) . Skripsi. Institut Pertanian Bogor, Bogor.

Wihardjaka, A. 2002. Pola perubahan ketersediaan kalium dalam tanah selama pertumbuhan padi di lahan sawah tadah hujan. J. Penelitian Pertanian Tanaman Pangan. 21(3):15-23.

Zubaidah, Y., R. Munir. 2007. Aktifitas pemupukan fosfor (P) pada lahan sawah dengan kandungan P-sedang. J.Solum. 4(1):1-4.

Zulputra, Wawan, Nelvia. .2014. Respon padi gogo (Oryza sativa L.) terhadap pemberian silikat dan pupuk fosfat pada tanah ultisol. J. Agroteknologi. 4(2): 110. 